\title{
Examining the Role of Non-Formal Education as a Conduit to Poverty Reduction and Rural Development: The Case of a Rural Community in a Municipality in
} Ghana

\author{
Emmanuel Intsiful \\ Institute of International Comparative Education, Beijing Normal University. \\ Email: emmafulkwabinaintsi@yahoo.com \\ Albert Martins \\ Department of Marketing. University of Professional Studies, Accra, Ghana
}

Received: December 13, 2018

doi:10.5296/jet.v6i2.13586
Accepted: March 9, 2019

Published: April 5, 2019

URL: http://dx.doi.org/10.5296/jet.v6i2.13586

\begin{abstract}
Non-formal education (NFE) programmes involve literacy and numerical programmes that aim at training people to read and write. Gaining such basic literacy skills enables a person to use the reading, writing and calculation to develop the self and the community as a whole. In the Ghanaian context, the Ministry of Education in the year 2000 established the National Functional Literacy Programme with the chief aim of making accessible literacy and life skills to the rural poor and the illiterate. The aim of this paper was to examine the extent to which non-formal education contributes to literacy improvement, poverty reduction and rural development in a rural community within a municipality in Ghana. The researchers employed Amartya Sen's capabilities approach to economic and human development and Paulo Freire's concept of education for conscientization.

The findings of the study show that the non-formal education programme plays a very critical role in the reduction of illiteracy coupled with improving the living standard of the rural adult learners, once the programme is well organized and implemented. Thus, the activities of NFE have the potential to make the illiterate poor become functionally literate which is a necessary condition for poverty reduction. Providing skill training is one of the major ways of improving the livelihood of poor people. Based on the impact of NFE activities on those who had graduated from the programme has the potential of reducing illiteracy and improving the standard of living of the people. The impact has been felt in areas like literacy and numeracy,
\end{abstract}




\section{MIMacrothink}

Journal of Education and Training

ISSN 2330-9709

2019, Vol.6, No.2

economic, social and political empowerment of learners in the community studied. However, the programme needs to be strengthened to address the issue of funding which has become a major challenge for the NFE. Facilitators and supervisors need enough motivation to commit them fully to the task and learners need support to start their own business to bring about meaningful poverty reduction.

Keywords: Non-Formal Education, Poverty Reduction, Rural Development, Rural Community, Ghana

\section{Introduction}

There is no doubt that formal education has gained much currency for a very long time. However, at the same time, there has been a growing emphasis on non-formal education (NFE). The writers argue that this could be as a result of clarion calls for global policies from UNESCO such as Education for All (EFA), Millennium Development Goals (MDGs), Sustainable Development Goals (SDGs) and the concept of lifelong learning. Non-formal education programmes involve literacy and numerical programmes which aim at training people to read and write. Gaining such basic literacy skills will enable a person to use the ability to read, write and calculate to develop oneself and the community as a whole (UNESCO, 2006). In essence, this implies that such literacy intervention programmes will help people residing in rural areas who have limited or no formal education to play socio-economic and civic roles towards personal and rural development. Despite the central emphasis on literacy which is a key part of non-formal education, the 2016 Global Education Monitoring Reports explicitly emphasize that about 758 million adults can neither read nor write and construct a simple sentence. It is against this background that the Incheon Declaration and the Education 2030 Framework for Action mandates countries to ensure the SDG 4; inclusive and equitable quality education and lifelong learning for all by 2030 (UNESCO, 2016).

In the Ghanaian context the Ministry of Education in the year 2000 established the National functional literacy programme with the main aim of making accessible literacy and life skills to the rural poor and the illiterate. The Non-Formal Education Division (NFED) of the Ministry of Education (MOE) is responsible for the implementation of the functional literacy programme which is to provide reading, writing and numeracy skills, and participation in community development and income generating activities (World Bank, 1999, p.11). This programme takes place in all the districts in Ghana, and runs a 21-month cycle. According to the Ghana Statistical Service (2018), 46\% of the population of Ghana (which is estimated at $29,682,848)$ are non-literate. It means that as many as about $13,654,110$ people are non-literate, and need such programmes to climb up the literacy ladder. Strikingly, about the same population size of 13,654,110 who are non-literate reside in rural areas in Ghana. The contents of the programme's curriculum include, issues on health, environment, civic awareness, income generating activities and education. The functional literacy classes are community based. The class carry out several activities in their respective communities towards the upliftment of the lives of the people and the development of the community. The non-formal literacy programmes (NFLP) serve as a platform for the poor and non-literate in society to make their voices heard. 


\section{Mll Macrothink}

Journal of Education and Training

ISSN 2330-9709

2019, Vol.6, No.2

At the same time following the Ghana Core Welfare Indicators Questionnaire (CWIQ) Survey (2016), " $64 \%$ of women are illiterate, as compared to $38 \%$ of men. In rural areas, $74 \%$ of household heads in the poorest income quintile were illiterate, compared to $15 \%$ in the richest quintile". Furthermore, figures from the Education for All (EFA) 2016 Global Monitoring Report indicates that, net enrolment rate into primary education in Ghana stands at about $63 \%$ while adult literacy rate stands at about 55\% (Global Monitoring Report, 2016). This implies that close to half of the adult population in Ghana is still non-literate.

Apart from some central township of district and municipal capitals in Ghana, the remaining inhabitants in rural areas comprise of people who could be described as living below the poverty line, as outlined by the United Nation (UN) criteria ( $\$ 1$ a day). The main occupation of these rural inhabitants is subsistence farming based on family labour, which portray their poverty situation. This could not allow most of these rural dwellers to have access to formal education, and the privileged few who have the opportunity may not go beyond the threshold of basic education. Parents sometimes cannot allow their children to go to school as they have to assist in farming activities to support their families. This has made non-literacy rate endemic in most rural communities. The Government of Ghana's strategy to make its citizens functionally literate, as part of achieving most of the UN's SDGs and lifelong learning, brought about the NFLP. The adult in rural areas are taking advantage of this programme to get themselves not only out of ignorance and poverty through education but also to empower themselves. This paper therefore seeks to examine the extent to which non-formal education has contributed to poverty reduction and rural development in some rural areas in Ghana.

In order to have a better understanding of this topic, this paper is structured in four sections. The first section provides a brief background context of Ghana and also a characterization of rural areas, to help provide an understanding of the reason and possible benefits of the introduction NFLP. The literature review and conceptual framework constitute the second section. In order to provide a scholarly underpinning of non-formal education and rural development, we conceptualized the three dimensions of adult literacy and argued that the combination of the three dimension will better equip adult learners with employable skills that will reduce poverty, raising consciousness and aid in rural development in the long run. We employed capabilities approach to economic and human development (Sen, 1993), and Paulo Freire's (1970) concept of education for conscientization and action for freedom. The third section provides in-depth discussion of the objectives of NFLP; how NFLP is organized and implemented; curriculum of the NFLP; challenges of NFLP and the role of the NFLP in poverty reduction, raising consciousness and rural development. The conclusion and policy recommendations on NFLP in Ghana constitute the final section of this paper.

\subsection{Background of Ghana and Characterization of Rural Areas}

In order to better appreciate the extent to which non-formal education serves as a mechanism to poverty reduction and rural development in some rural areas in Ghana, it is very significant to understand the context of both the country and a description of where these adult learners reside. 


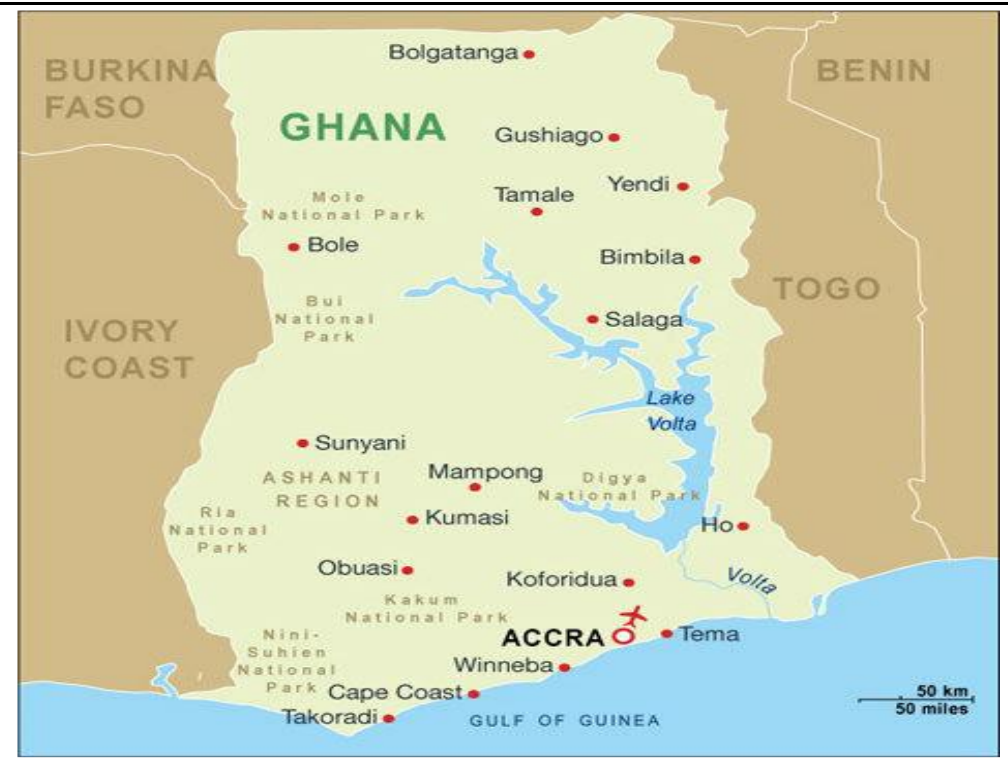

Figure 1. The map of Ghana

Ghana is a country located in the West Africa, and it is the first Sub-Saharan African country to gain independence. As seen in the map above, Ghana shares borders with Togo and Ivory Coast to the east and west respectively, Burkina Faso to the north and the Gulf of Guinea to the South.

Ghana's economy can be classified as agrarian. This stems from the fact that agriculture forms a major part of Ghana's economy. Again, mining and tourism also play a vital role. From records, the GSS (2018) indicates that gold alone accounts for about $30 \%$ of Ghana's foreign exchange earnings. Ghana is also a major producer of cocoa, and has attained the position of the second largest producer of cocoa in the world for the past fifteen years.

Currently, Ghana's population is estimated at about 29,682,848 (Ghana Statistical Service, 2018). The share of Ghana's rural population is about $43 \%$, this means that about $12,763,650$ resides in the rural area (GSS, 2018). Moving to economic indicators, Ghana's GDP per capita for 2017 was $\$ 1539$. The educational system in Ghana is both formal and non-formal. Nonformal education to some extent forms part of Ghana's educational system but is organized for the non-literate population and primary school drop-outs to equip them with literacy, numeracy and life skills. The non-formal education classes run in the evenings for adults non-literates cycle programme. Also, the government of Ghana launched the Free Compulsory Universal Basic Education (FCUBE) programme in 1996 with the aim of providing opportunity for all school going children to "receive quality basic education" (UNESCO, 2007a).

A rural area called Nsanfo is located in the Mfantseman municipality in the Central Region of Ghana. Mfantseman is located in the south-eastern part of Ghana with about 233,135 inhabitants (GSS, 2018). It lies on latitude $6^{\circ} 35^{\prime} 0^{\prime \prime}$ 'North and longitude $0^{\circ} 28^{\prime} 0^{\prime \prime}$ 'East and covers an area of $2361 \mathrm{~km}^{2}$ (World Map, 2018). The Mfantseman municipality is about $165 \mathrm{~km}$ south of Accra, the capital city of Ghana (Driving Distances in Ghana 2017). The people of the 


\section{Macrothink}

Mfantseman municipality are from the Fanti ethnic group and their main occupation is farming on subsistence basis. They also engage in petty trade, especially in food crops. It does not have access to the sea, and so does not enjoy coastal facilities

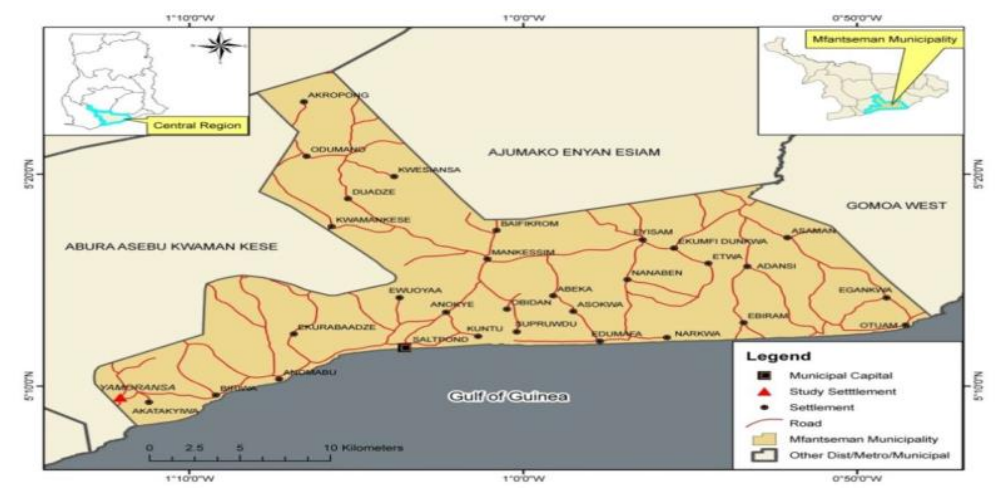

Figure 2. A map of Mfantseman municipality

Most of the roads in the municipality are untarred (gravel or earth-surfaced), and get severely damaged with rainfall. The result is that they become unmemorable; hence the difficulties faced by the rural folks in transporting their harvest to the market centers in the municipality, leading to post harvest losses. Like most rural areas in Ghana, Mfantseman experiences two seasons of rainfall; the major season between May and August, and the minor season between August and November. During these times, the people engage in active agricultural activities. They use simple agricultural tools such as cutlasses and hoes in the cultivation of crops. This is labour intensive, and therefore their children assist in the farms as help- hands. This makes the children abandon school to take up farming, contributing to the high rate of illiteracy in the municipality.

Some of the crops grown in the municipality are maize, yam, cassava, groundnuts and vegetables, and on small holdings due to low agricultural technology. The people are mainly peasant farmers and petty traders; therefore, membership of the literacy classes is made up of those who have never been to school, school dropouts, petty traders, peasant farmers and the unemployed living in high poverty situations. These people are into some trading and agricultural activities, so they cannot be described as the poorest of the poor. They are just like the other community members who are not part of the NFLP. The only difference might be that they are interested in building upon their literacy levels and acquiring additional income generation skills that will help them raise both their social and financial status.

\section{Literature Review and Conceptual Framework}

In this brief literature review we draw a logical relationship between non-formal education and adult literacy programmes. We conceptualize the three dimensions of adult literacy and argue that the combination of the three dimension will better equip adult learners with employable skills that will reduce poverty, raise consciousness and aid in rural development in the long run. The capabilities approach to economic and human development (Sen, 1993), and on Paulo Freire's (1970) concept of education for conscientization and action for freedom are employed.

Drawing on the Ghanaian perspective, the non-formal education is purposely designed for adult 


\section{Mll Macrothink}

Journal of Education and Training

ISSN 2330-9709

2019, Vol.6, No.2

illiterate residing in rural areas. As mentioned previously the objective of the non-formal education is to educate rural adults to achieve literacy skills since it is argued to be a vital part of adult education and lifelong learning concept propagated by UNESCO. In this regard, literacy does not only deal with the ability to write, read and calculate but most importantly "to identify, understand, interpret, create, communicate and compute, using printed and written materials, as well as the ability to solve problems in an increasingly technological and information-rich environment" (UNESCO, 2016, p. 2). This we argue also captures the functional dimension of literacy education and is geared towards preparing the individual towards performing social, economic, and civic roles in the community. Examples of such roles are the reading and understanding of the environment surrounding the individual, effective management of the home and family, improvement in employment and income generation, and active participation in community or rural development activities (Freire, 2004).

At the same time education also involves both formal and informal learning that span the whole life of the individual, and also reflects the needs and aspirations of the individual and leads to a permanent change in behaviour. In Freire's (2004) view, adult literacy education is a process to liberate the adult illiterate population from oppression. We argue that that non-formal literacy education in rural areas is an avenue to raise their consciousness and regain their humanity. In this line of reasoning adult learners in rural areas through discussions, deal with real-life issues which helps them develop real-life problem solving capabilities, while the facilitator helps to build up their reading, writing and calculation skills (Freire, 2004).

Furthermore, we conceptualize literacy into three dimensions: Functional and Participatory Literacy; Critical Literacy and Cultural Literacy. The Functional and Participatory Literacy perspective views the adult learner in the rural area as a key component of the rural area, hence engages the learner as a focal point in building up his/her literacy experience by constantly engaging in both the design and implementation of the literacy activities. We argue that this approach will build up the adult learner to take active part in developing himself/herself as well as the community in which $\mathrm{s} / \mathrm{he}$ resides, in this case the rural areas within the Mfantseman municipality where these adult learners live. Secondly, cultural literacy set a very clear linkage between learning and culture. This literally implies that the mechanism and process of learning should be based on the cultural setting or context of the learner. In this case, during literacy class, what the adult learners read and discuss should be based on their cultural setting, which is their values, beliefs, customs, norms and practices of the rural community, thereby protecting and preserving the culture of the various communities. Critical literacy which is the third dimension for this paper involves the empowerment and freedom of the adult learner through consciousness building. This positions the adult learner to make critical analyses of problems, challenges and negative activities in the rural community and working towards their reversal.

Following the above three dimension and perspectives of literacy, putting these three perspectives together seek to stimulate and provoke the adult learner to critically analyse issues around him/her and be able to suggest practical solutions that will lead to his/her personal development and that of the rural community, all within the cultural setting (Subban, 2007; Freire, 2004).

Poverty is one of the key characteristics that can be found in rural areas. It is characterized by 
a situation in which there is the deprivation of social and economic facilities such as good income, good health care, employment, education, food supply, and decent housing. We also argue that it also includes psychological dispositions such as shame, exploitation, discrimination, lack of power and fear. Since education is a tool to ensure development, adult education programmes in rural areas are based on vocational, agricultural training and education in order to equip these adult learners in the rural areas with the necessary employable skills. Hence, the non-formal education is a deliberate attempt by the Government of Ghana to better the lives of the rural indigenous people by reducing poverty levels.

The final poverty reduction strategy is rooted in the responsibility of government in ensuring equitable distribution of wealth and resources. This is done through effective state structures and functions such as a vibrant local government administration that takes up local development issues, effective representative democracy that would represent the aggregate views of the citizens, and a dynamic civil society with strong collaborative and negotiation skills that involves the participation of the citizens in a free environment (World Bank, 2004; Van Der Veen \& Preece, 2005; EFA, 2006). Following the above arguments made, adult literacy programmes do not only empower individuals to reduce poverty alone but also it has a ripple effect of positive development of the entire community.

Rural development is described as the process of promoting the living conditions of the people in a rural community as a whole through the active participation of the people. Community development comprise of a better income generation and its equitable distribution, improved employment opportunities and the improvement in basic social amenities such as food, health and housing facilities. Also, community development revolves around elements such as selfhelp, which means the initiative and active participation of the people; felt needs, which implies the actual needs of the communities; and the holistic development of a community. In other words, the development that goes in favour of the majority. Community development include agricultural education and development, health education, the development of cooperatives and rural industries, the provision of social amenities, the provision of socio-economic infrastructure, and the development of sports and entertainment. Also, all the approaches to community development outlined in the literature review are fused into the principles and values of community development outlined by Subban (2007).

This in turn leads to the empowerment of the members of the communities, practitioners and organisations that work through networking to bring development into the disadvantaged communities. In the face of the fast ever-changing outlook of communities, Subban (2007) suggests that community development requires constant learning and reflection to increase community capacity, develop assets, and engage in innovate thinking and critical action. (Subban, 2007, p. 77). Continuous effort, which is sustained through the members of the community, is the potent way to maintaining community capacity in rural and disadvantaged communities (Subban, 2007; Dovlo, 2006).

\section{Conceptual Framework}

The conceptual framework for examining and understanding the role/impact of Non-formal education among adult rural learners of empowerment, poverty reduction and rural 


\section{Macrothink Mnstitute"'}

development is based on Amartya Sen's Capabilities Approach (1993) to economic and human development, and on Paulo Freire's (1970) concept of education for conscientization and action for freedom. Noble Laurette winner, Amartya Sen argues that what really matters when assessing human's well-being is people's capabilities; which means emphasis should be placed on what people can do or be rather than on income and wealth. Hence, in connecting the issue of non-formal education in the rural areas in Ghana, the capabilities framework is concerned with the generation of capabilities and agency (rural adult learners). Education is important in acquiring human capabilities through the acquisition of literacy, cognitive, moral, emotional, physical and social skills. These skills form capabilities for active citizenship and gainful employment. At the same time it is the social, environmental and personal factors that will determine to what extent human capabilities can be generated.

The focus of Paulo Freire (2004) is on human agency through education for social transformation. According to him, schooling is not education: rather it is cultural action for freedom and therefore an act of knowing and not of memorization. He further argues that education is conscientization which is the process for achieving awareness of socio-cultural reality and shapes one's capacity to transform reality. Any system which does not develop consciousness/awareness of one's condition is not education in the real sense. This conscientization then leads to praxis or action/agency. In the case of non-formal education, the underlying assumption derived from both approaches underlines the individual aspect of education, i.e. conscientization. Hence, it through this idea, that the Government of Ghana through the NFED under the Ministry of Education in Ghana is investing in education especially for adult learners. We argue that if this conscientization is created among adult learners, in the long run the society will be the beneficiaries of the returns.

\section{Role/Objective of Non-Formal Learning Programme (NFLP) in Ghana}

The NFLP was introduced in the year 2000 by the Government of Ghana with the main objective to provide literacy and life skills to the non-literate and the rural poor Ghanaian population. In the World Bank's project appraisal document on Ghana's NFLP, the World Bank argues that someone who has become functionally literate should be able to engage in activities that require literacy for effective functioning of the group s/he belongs to, and also be able to apply the reading, writing and calculation skills for his/her personal development and that of his/her community (World Bank, 1999, p. 16).

Again, following the same objective, Blunch and Portner (2004) carried out an extensive discussion on the objectives of setting up the NFLP. They posited that the non-formal education programme is aimed at providing the adult learners with functional literacy skills in order to fulfil the following conditions: The facilitation of the country's process of development as development becomes faster in a society with more literate people; increase in the enrolment levels in the basic schools as more parents will be willing to send their wards to school because they have become aware of the advantages of education; the reduction of poverty and disease by virtue of the adult learners' application of the functional, developmental and occupational tasks in the primers used; and the effective functioning of the adult learner in the larger socioeconomic and political environment by means of improved communication and social 


\section{Macrothink}

interaction. The others are the harnessing of the talents of the adult learners for the country's social, economic and political progression, and the improvement in the adult learners' skills and self-esteem to be able to make informed choices in everyday life activities such as family planning, personal hygiene and general health issues (Blunch \& Portner, 2004, p. 38).

Owusu-Mensah (2007) broke down the objectives of the NFLP into four distinct parts: adult literacy and numeracy, life skills training, income-generation and occupational skills and civil awareness. Regarding the adult literacy and numeracy, the NFED (1999) outlined the objectives of the programme ran by the NFED for the adult learners as to "enable participants to better meet their personal or social needs through enhancing their abilities to deal competently with everyday life in literate communities; equip learners with the knowledge, attitudes and skills that will enable them raise the quality of life in their communities; enable learners to improve upon occupational skills through functional literacy; and broaden the reading interests of learners and establish an attitude of reading for pleasure through the provision of follow-up literacy supplementary reading materials" (Owusu-Mensah, 2007, p. 8).

In summary, one can argue that, looking at the above- mentioned objective of NFEP is to tackle the inequalities in access to literacy and life skills, which is meant for target groups such as the rural communities and women, thereby getting them to become part of the country's developmental efforts. Also, under the income-generation and occupational skills, OwusuMensah (2007) posits that the programme aims to equip the adult learners with occupational skills that will further assist them in generating additional income. After stating the objective of the NFEP and why it was established, the next section will show in brief, how the NFEP is implemented and organized in Ghana.

\subsection{How is the NFEP in Ghana Implemented and Organized?}

The NFED is solely responsible for the following; policy formulation, coordination of the programme, design and implementation of the programme, curriculum design and production, radio programme development, entire supervision of NFEP, evaluation and monitoring of the programme. All these functions are anchored within three main departments, i.e. materials development department, logistics department and research and monitoring department. A facilitator is in charge for both teaching and learning. It is key to point out that the selection of the facilitator must be approved by community leaders. When the facility is approved $\mathrm{s} / \mathrm{he}$ undergoes a mandatory training course for three weeks (21 days). This training is organized at the beginning of every cycle for new facilitators, which covers class administration, pedagogy, curriculum content, testing, counselling, and community mobilization skills (NFED, 2009).

During the NFEP cycle, facilitators undergo refresher courses. The NFEP runs in cycles of approximately 21 months. It usually begins in October/November and ends in June/July. Each cycle has a batch of learners. On average, learners meet for six hours per week. Class meeting times are decided by learners and their facilitators. Some classes meet early in the morning while others meet in the evening. Most classes are held in the evening since most adult learners work as farmers, fishermen and traders. There are usually 25 learners in a class. This makes it easy for learners to get individual attention from facilitators.

Classes are assessed at the end of a cycle, and learners who complete the cycle are expected to 


\section{Macrothink $\Lambda$ Institute"'}

participate in the end of cycle assessment exercise. This assessment is done in 3 stages. The first stage is the class level which will be conducted by the facilitator, followed by zonal level which is conducted by supervisor/service providers and finally, the national level which is conducted by NFED. Each learner completing the literacy cycle is awarded a certificate of participation. It is estimated that between 1992 and 1998 at least one million non-literate Ghanaians became functionally literate in their mother tongue (NFED, 2004b). Within the district, the district head is the chief operating officer of NFED in each district. Resources for the classes, including the Primer (textbook), facilitators manual (NFLP) and other inputs such as pens, class attendance book are channeled through the District Offices from the Headquarters. Classes are directly supervised by Zonal Supervisors, who are in turn supervised by District Office staff. Officers from the Regional Office and the National Office also undertake monitoring and supervision occasionally (NFED, 2000). Having known how the entire NFEP is organized and implemented, the next section will discuss in brief what is learnt during classes and how is it learnt (curriculum issues).

\subsection{What is Learnt and How is it Learnt in NFLP in Rural Areas in Ghana?}

As mentioned before the chief aim of NFLP in Ghana is to train rural adult learners to become functionally literate not only for their individual benefits but also for their society at large. The contents of the curriculum included topics and issues that had to deal directly with the overall human and rural development; issues that had to do with the improvement of the adult learners and the community's socio-economic conditions. A document of NFLP reiterated that topics in the NFLP are related to everyday life. These include:

"good drinking water, good sanitation, keeping of accounts, irrigation/modern methods of farming and fishing, immunization, kwashiorkor (lack of protein), teenage pregnancy, HIV/AIDS, drug abuse, taxation, animal husbandry, intestate succession law (PNDC Law 111), community empowerment, child labour, bush fires, personal hygiene, weaving, alcohol brewing, tree growing, marriage, nutrition, food preservation, expensive funerals, family planning, puberty rites, national and local level elections, " (NFLP, 2004, p. 20).

Delivering the above topics as cited in the NFLP curriculum is seen to be in congruence with the propositions of Van Der Veen and Preece (2005) and Narayan (2000) about strategies of poverty reduction. These two scholars argued that rural development by means of poverty reduction could be realized through; vocational education, agricultural extension training and effective community participation. It is against this background, that adult learners in these rural areas are taught lessons on irrigation/modern methods of farming and fishing, animal husbandry, bush fires, tree growing and the likes. These could be essential in equipping the learners with recent agricultural knowledge aimed at improving their yield and reducing postharvest loses, despite the problems and costs that come with it.

Also, topics such as good drinking water, good sanitation, immunization, kwashiorkor, teenage pregnancy, HIV/AIDS, drug abuse, personal hygiene, nutrition, etc. could also be an avenue that would help to improve the adult learners' knowledge in promoting good health and personal wellbeing (UNESCO, 2015). Following these topics that adult learners are exposed to during their literacy classes in rural areas in Ghana, we argue that living in good health 


\section{Macrothink Mnstitute"'}

signifies less spending in seeking healthcare, and a stronger labour will further save the learners more money in their pocket. When the people are healthy, they work more and earn morepersonal and rural development. The government could also use this as an opportunity to save a lot of resources that could be channeled into other sectors of rural development.

On the positive effects of these topics, a study conducted by Agodzo (2014) in some selected rural communities in Ghana indicates that the above lessons help in both the learners' individual development and that of their rural communities. Again, lessons on keeping accounts, weaving, alcohol brewing, starting a small business could help in inculcating into the learners some sort of vocational training with which they may make additional income to support their living and that of their family. Also, topics such as taxation, intestate succession law, rural empowerment, child labour, marriage, expensive funerals, family planning, national and local elections, etc. are avenues in helping the learners to broaden their horizon on social and civic awareness (UNESCO, 2015). Through this topics discussed, we argue that adult learners become active citizens as they engage themselves in sharing ideas on what is right for their rural community.

The NFED has therefore claimed to adopt a unique method for the NFLP lessons in the respective classes. The teaching approach involved descriptions, discussions and debates on pertinent topics or issues especially experienced in the various communities. This makes the lesson being placed in the concrete realm and that enhances the active participation of the learners. This could be described in one school of thought as 'learning by doing'. The above methods of teaching the adult learners outlined fall in line with both the dialogue and the problem-posing approaches to the process of adult education posited by Freire (2004). This stems from the fact that it helps to open the avenue for effective communication between the learners and also between the learners and facilitators. Such discussions generated by the pictures, stories, dramas, etc. help to elicit the expression of views by the learners on real life situations, thus helping in identifying causes and effects of real life problems and finding practicable solutions to them.

\subsection{Examining the Relationship between NFLP and Poverty Reduction through Income Generating Activities in Rural Ghana?}

Following the NFED curriculum used in Ghana, there are two main activities in which adult learners are exposed to. These are the core literacy lessons and income generation training. The literacy lessons cover the first half of the programme as the income generating activities (IGAs)/occupational skills cover the second. Therefore, livelihood activities are introduced in the last year of the NFLP where the learners are trained to acquire income generation skills to help them increase their sources of income to support their lives. Several IGAs are taught in the class, but one is selected by the class and embarked upon as their group IGA. However, individual learners also take up any of the IGAs taught as his/her main occupation or additional source of income. This is one of the reasons why the NFLP is targeted at the rural areas where poverty is endemic, for which the four areas of this research are part. The topics treated under income-generation/occupational skills include cocoa farming, maize cultivation, dry season farming, basket weaving, animal husbandry, bee-keeping, oil palm cultivation, borrowing money for work, hygienic way of preserving and selling fish, farm extension services, pottery and soap making(NFED-MOE, 2008). 


\section{Macrothink Mnstitute"'}

In order to translate the topics taught in the classroom to reality organizations such as the National Board for Small Scale Industries (NBSSI) and World Vision, Ghana are also involved in the income generating activities. Following Blunch and Portner (2004) these two organizations are responsible for the training of learners in the formation of co-operatives, simple accounting processes and entrepreneurship and the GRATIS Foundation, which provides training entrepreneurship for income-generating activities.

Normally, the NFED engages the services of experts to serve as resource persons in teaching the adult learners these IGAs and design simple literature for the IGAs. In the some communities in Ghana, the area is partly rain forest and partly savannah, so the people mostly engage in some plantation and food crops such as maize, groundnuts, cassava, yam, plantain, citrus fruits and vegetables. Therefore, the literacy classes took up IGAs around these activities.

A research conducted by Plan Ghana, a non-governmental organization in 2015 clearly showed that, the literacy class enabled rural adult learners to take up many vocations as their income generating activity. For instance, according to a facilitator, some of the adult learners in a class individually dealt in oil palm plantations and sold their fruits to the group, thereby getting some source of ready market for their goods and making extra income for themselves. One way of adding extra income to their products is the added value given to their products through packaging. This ideas of added value we argue would have been impossible without the literacy classes, as these individual learners found the need to form cooperatives and use the knowledge acquired during the literacy classes to package their products and form a cooperative group. The cooperative group from these individual learners gave them a much stronger bargaining power for their products. In order to enhance the concept of praxis as espoused by Freire (2004), the literacy classes employ both theory and practice in order to achieve action. For example, a literacy class produced about 120-180 liters (18-38 gallons) every market day (the market day in the community is held on every Saturday of the week). What this meant was that in a month, adult learners in the class produced 480-720 liters (72-152 gallons). Through the cooperatives association formed, they had a better price for their products to the factory in the district in which they had a higher price.

The adult learners stated that if it had not been the knowledge they had in the adult literacy programme, they would have sold their products individually during market days, which would not give them enough money, besides non-payment challenges. In effect the literacy classes had aided them to improve on their income levels and enabled them to cater for their family needs. Again with the knowledge acquired with the income generating activity course in the curriculum, the by-products of the palm oil production also became useful for the group. The palm kernels were either cracked and used to produce palm-kernel oil or sold out to palmkernel oil producers at the factories. Also, the outer fiber of the palm fruit was dried and used as fire fighters, thereby reducing the use of fossil fuels such as kerosene and gasoline to light up fire. This is a process which helps conserve the environment.

Furthermore, the adult learners are also taught how to access credit either from the banks or to form co-operatives to finance their economic ventures. These activities are meant for all adults and youth but have a special focus for those who are unemployed so that they will learn some of the occupational skills to make a living. Since different parts of Ghana have different 


\section{Macrothink Mnstitute"'}

economic activities, the type of occupational skills taught in a particular community reflects the economic activities dominant in that area. For example, whilst farmers in the cocoa growing areas in the forest zone learn skills associated with cocoa production, those in the coastal areas discuss how to improve skills in fishing and fish mongering as fishing and fish selling constitute the main economic activities along the coastal rural areas.

It could be clearly seen from the above module that NFE and rural poverty have positive relationship. This is because when the module is well operationalized it could help the rural poor to improve their living standards through income generating activities. Thus, they can afford to pay children school fees, drink potable water, access quality healthcare and eat nutritional food because their income will increase. The next section will discuss in brief the role of NFLP on like skills training and raising consciousness in health issues.

\subsubsection{The Role of NFLP on Life-Skills Training and Health Issues}

One of the major services of the NFE in Ghana is training in life-skills and is about how to keep healthy (NFED, 2008). A number of both national and international organisations are involved in this activity. Three of such organisations are the Planned Parenthood Association of Ghana (PPAG), Green Earth Organisation and the World Vision, Ghana. This service is intended to help participants maintain personal and environmental hygiene in order to have a healthy life (Blunch \& Portner, 2004). The social and health issues covered under this service include: family planning, teenage pregnancy, environmental hygiene, immunization, HIV AIDS, safe motherhood and child care, drug abuse, traditional medicine and safe drinking water. It follows therefore that once learners are able to achieve the goal of this module of NFEP, they would be able to improve their health status and have the potential of improving their living standards. This is because they will be healthy to embark on their economic activities; their health care bills will go down and all things being equal improve their savings and also enhance economic development for poverty reduction. There is a link between poverty reduction and skills training and increased growth, productivity and innovation, in particular for the informal sector (Fluitman, 2002).

To sum it up, a study conducted by Atchoarena and Gasperini (2003) argues that skills development improves output, quality, diversity and occupational safety and improves health, thereby increasing incomes and livelihoods of the poor. It also helps to develop social capital and strengthens knowledge about informal sector associations, rural organizations and governance. Following the tenets of the human capital theory, the better educated the agricultural labour, the higher their productivity.

\subsubsection{The Role of NFEP on Rural Development}

The NFLP classes have some of their lessons and topics bothering on rural community development activities and ways of helping in developing a strong and healthy community. It also inculcates into the learners the sense of patriotism and active participation in community development projects. A study conducted by Dovlo (2006) states that NFLP has inculcated in adult learners an avenue where they come together to undertake community projects such as clearing and sweeping their immediate surroundings, desilting chocked drains, and cleaning around their wells and streams where they draw water. Again on the role of NFLP on rural 


\section{Macrothink Mnstitute}

development, Adult learners undertake self-help projects such as filling of potholes on their feeder roads to make the roads motorable to improve movement of people and goods; provide labour, expertise and some materials in building schools, health-posts, marketplaces, places of convenience, digging wells for water (Plan Ghana, 2012). It is always the case that members of the literacy class initiate and lead these communal projects, they claimed.

Also the building of the places of convenience would help in a way to prevent people from easing themselves off in the nearby bushes, which pollute the environment. In addition, the clearing and cleaning of the surrounding and riversides, relocation of the refuse dump, and the cleaning of the market places also lead to a clean community. This in turn will lead in a way to a community that will generally be inhabited by healthy people. Good health is one of the factors underlying development; therefore a clean and healthy community will be one that can be described as experiencing economic and social development.

In addition, the planting of trees that is being supported by the adult literacy groups (which normally takes place once in a month, especially during the wet season, and with the collaboration of the forest commission and the Ministries for Agriculture and Environment) also contributes to stabilizing weather patterns which could in turn help agricultural activities, plant and animal life. This activity helps in carbon sequestration, thereby providing the communities with a cleaner atmosphere. The trees may also serve as wind breaks thereby preventing storms and reducing the intensity of hurricanes affecting the communities.

The above rural development activities are in a way linked to the participatory literacy perspective as posited by Subban (2007). This is the perspective where the above activities fit into the recognition and diagnosis of the needs and interests of the communities by the learners, and pooling resources to address them. It also falls under the community-based literacy perspective outlined by Subban (2007), which focuses attention on finding problems affecting the learners' communities and designing and executing the possible solutions to the problems. Having discussed the role of NFLP, the next section will outline the problems faced by adult learners in the NFLP programme.

\subsection{Challenges Faced by the Adult Learners in the NFLP Programme}

Since most of these adult learners are farmers, one of the challenges these adult learners experience is that when farming season begins most of these adults learners have to abandon these literacy classes in order to concentrate on their farming. This is because the farming is their only livelihood activity. After spending their entire days at their various farms, the adult learners become tired and exhausted and cannot attend literacy classes.

Secondly as a result of the old age of most adult learners, some complained about their poor eyesight which made it extremely difficult for them to keep pace with the lessons and other activities. A research study conducted by Dovlo (2006) highlights that the 21 -month duration is actually less, as most of the groups could not complete the NFLP curriculum within the 21month period. It could be due mainly to, among other things, the overloading of the curriculum. Another issue that bothered most of the learners was the problem of forgetfulness. Learners claimed that most often they tended to forget what they learnt from previous lessons, making it difficult to follow the current lessons as they were build-ups on the previous ones. 


\section{Macrothink Mnstitute"'}

Some of the facilitators also absented themselves from classes due to issues including noncommitment and taking up their personal activities to take care of themselves. This stems from the fact that the facilitator position was purely a voluntary one, so facilitators did not have the motivation to attend classes' regularly.

\subsection{Conclusions and Recommendations}

Non-formal Education, we argue could be seen as a result of clarion calls for global policies from UNESCO such as Education for All (EFA), Millennium Development Goals (MDGs), Sustainable Development Goals (SDGs) and the concept of lifelong learning. Non-formal education programmes which involve literacy and numerical programmes aim to train people to read and write. Gaining such basic literacy skills enables a person to use the reading, writing and calculation to develop oneself and the community as a whole. In the Ghanaian context the Ministry of Education in the year 2000 established the National functional literacy programme with the main aim of making accessible literacy and life skills to the rural poor and the illiterate. Hence the aim of this paper sought to examine the extent to which the non-formal education sector contributed to literacy improvement, poverty reduction and rural development in the Mfantseman municipality of Ghana.

Following the above discussions, it could be clearly seen that the Non-formal education programme, when well organized and implemented, could play a very critical role in the reduction of illiteracy coupled with improving the living standard of the rural adult learners. Thus, the activities of NFE have the potential to make the illiterate poor become functionally literate which is a necessary condition for poverty reduction and hence national development. Providing skills training is one of the major ways of improving the livelihood of poor people. The programme has the potential of reducing illiteracy and improving the standard of living of the rural people. The impact has been felt in areas like literacy and numeracy, economic, social and political empowerment of learners in the two districts studied.

However, the programme needs to be strengthened to address the issue of funding which has become a major challenge for the NFE. Facilitators and supervisors need enough motivation to commit themselves fully to the task and learners need support to start their own business to bring about meaningful poverty reduction.

\subsubsection{Recommendations}

The first recommendation for the Non-formal education Division under the Ministry of Education in Ghana is to introduce some monthly payment of allowance for their voluntary facilitators. This will motivate them to work very well as expected. Again it will help reduce the problem of absenteeism among most facilitators since absenteeism is accounted for as one of the challenges hindering the effective delivery of literacy classes. The key actors of the Nonformal education should help streamline and provide recognition and accreditation of NFE certificates since this can allow learners to use the certificate to apply for vocational jobs. This will go a long way to help in achieving the main goal of making learners functional literates and improve their living standards.

Secondly, there should be increase in the yearly budgetary funding for the non-formal 


\section{MInstitute Macrothink $^{m}$}

education programme by the central government. Again the local government should aid in the operational activities of the literacy programme since there is a major challenge of funding for the programme. Additional funding should be sourced to close-up the funding gap from donor agencies such as IFAD, DVV, UNESCO and World Bank. When adequate funding is available it will help achieve the SDG goal 4 by 2030 .

Another vital recommendation is that NFEP should aid learners to have access to loans. This is because, requiring loans from the bank is cumbersome in Ghana and most importantly the collateral security which is required by most of these financial institutions can hardly be met by these rural adult learners. We recommend therefore, that since the curriculum places most emphasis on income generating activities coupled with inculcating the spirit of forming strong association, the programme can enter into a memorandum of understanding (MoU) with financial institutions to provide capital with minimal requirement and interest for these adult learners in order to enhance their IGAs. This we argue will go a long way to reduce poverty.

\section{References}

Atchoarena, D., \& Gasperini, L. (2003). Education for Rural Development: Towards New Policy Responses. Rome, FAO and UNESCO.

Blunch, N. H., \& Portner, C. C. (2004). Adult Literacy Programmes in Ghana. Human Development Network Education Department, World Bank.

Dorvlo, L. K. (2006). Essays on Community Development in Ghana. Maxvin Publicity Enterprise Ltd., Ho.

Driving Distances in Ghana. (2018). Retrieved from http:/ho.ghananet.com/Driving_Distances.aspx

EFA Global Monitoring Report. (2006). Regional Overview: Sub-Saharan Africa. Retrieved from http://unesdoc.unesco.org/images/0014/001497/149776E.pdf

Freire, P. (2004). The Banking Concept of Education. In A. Canestrani \& B. Marlow (Eds.), Educational Foundations: An Anthropology of Critical Readings. SAGE Publications Ltd, London.

Ghana Statistical Service. (2018). Ghana in Figures. Retrieved from http://www.statsghana.gov.gh/GhanainFigures_Pub.html

NFED. (2004a). Handbook of facilitation for NFLP Ashanti Region. Kumasi-Ghana, MOE/NFED.

NFED. (2004b). National Non Formal Education Policy Frame Work (DRAFT). Accra-Ghana, Continental Consultants Ghana Limited.

NFLP. (2004). Project Appraisal Document on a Proposed Credit in the Amount of Sdr23.7 Million (Us\$32.0 Million Equivalent) to the Republic Of Ghana for the National Functional Literacy Program. Report No. 18997 - GH.

Non-Formal Education Division (NFED)- Ministry of Education. (2008). Field Operations 


\section{Macrothink

Section-Information Manual.

Non-Formal Education Division (NFED)- Ministry of Education. (2000). National Functional Literacy Programme (Phase II): Programme Implementation Plan (2000-2005).

Non-Formal Education Division (NFED)- Ministry of Education. (2009). Field Operations Section- Information Manual.

Owusu-Mensah, F. (2007). Ghana Non-formal Education, Country profile prepared for the Education for All Global Monitoring Report 2008. UNESCO, 2008/ED/EFA/MRT/PI/56.

Sen, A. K. (1993). Capability and Well-being. In M. C. Nussbaum \& A. K. Sen (Eds.), The Quality of Life (pp. 30-53). Oxford: Clarendon Press.

Subban, J. E. (2007). Adult Literacy Education and Community Development. Journal of Community Practice, 15, 1. Routledge.

UNESCO. (2006). Why Literacy Matters. In UNESCO (Ed.), Education for All. Literacy for Life-ED2005/P1/01, Paris 07 SP, UNESCO Publishing.

UNESCO. (2007a). Free Compulsory Basic Education Programme (FCUBE) Ghana, 2007. Retrieved from http://webapps01.un.org/nvp/frontend!policy.action?id=141

Van Der Veen, R. (2003). Community Development as Citizen Education. International Journal of Lifelong Education, 22, 6. Routledge.

Van Der Veen, R., \& Preece, J. (2005). Poverty Reduction and Adult Education: Beyond Basic Education. International Journal of Lifelong Education, 24, 5. Routledge.

World Bank Document. (1999, May). Project Appraisal Document on a Proposed Credit to the Republic of Ghana for the National Functional Literacy Program. Report No. 18997-GH.

World Bank. (1997). Ghana Core Welfare Indicators Questionnaire Survey. Retrieved from http://siteresources.worldbank.org/INTSTATINAFR/Resources/ghcoreinds.pdf

World Bank. (2004). World Bank Development Indicators 2004. Washington, DC.

World Map. (2018). Saltpond, Ghana. Retrieved from http://www.traveljournals.net/explore/ghana/map/m2867328/saltpond.html

\section{Copyright Disclaimer}

Copyright reserved by the author(s).

This article is an open-access article distributed under the terms and conditions of the Creative Commons Attribution license (http://creativecommons.org/licenses/by/3.0/). 